\title{
Cost of territorial maintenance by Parodon nasus (Osteichthyes: Parodontidae) in a Neotropical stream
}

\author{
Samuel Elias Silva ${ }^{1}$, Wilhan R. C. Assunção ${ }^{1}$, Charles Duca ${ }^{2}$ and Jerry Penha ${ }^{3}$
}

The combined demand over a certain resource may exceed its immediate supply, which can then lead to competition between individuals. This competition may result in territorial behavior. In this study we determine the density and spatial distribution, describe the interactions arising from territorial behavior and evaluate the costs of keeping the territories defended by adults of Parodon nasus. The study was conducted in Camarinha Stream located in the Serra das Araras Ecological Station, Porto Estrela, State of Mato Grosso, Brazil. The density was constant throughout the length of the stream, with a mean ( \pm standard deviation) of 1.01 ind. $/ \mathrm{m}^{2}( \pm 0.14)$. Our results show that the spatial distribution of individuals in the area ranged between uniform and random. The territories were defended more often against intraspecific than interspecific intruders. The time that the owners of the territories devoted to defending them was not influenced by the size of the territories. However, owners of larger territories spent more time foraging than owners of smaller territories. As a result, owners of larger territories had less time to rest than owners of smaller territories. The results of this study show behavioral patterns relevant to understanding the relationship between size and territorial maintenance cost of $P$. nasus and other species of fish with territorial behavior.

A demanda combinada por um recurso pode exceder a sua oferta imediata, levando os indivíduos a competirem. Essa competição pode resultar no comportamento de territorialidade. Neste trabalho nós determinamos a densidade e a distribuição espacial, descrevemos as interações decorrentes do comportamento territorial e avaliamos os custos de manutenção dos territórios defendidos por indivíduos adultos de Parodon nasus. O estudo foi realizado no córrego Camarinha localizado na Estação Ecológica Serra das Araras no município de Porto Estrela, Mato Grosso, Brasil. A densidade foi constante ao longo de todos os trechos, com média ( \pm desvio padrão) de 1,01 ind./ $\mathrm{m}^{2}( \pm 0,14)$. Nossos resultados mostram que a distribuição espacial dos indivíduos na área variou entre uniforme e aleatória. Os territórios foram defendidos mais frequentemente contra invasores intra do que interespecíficos. O tempo que os detentores de território dedicaram a sua defesa não foi influenciado pelo tamanho dos territórios. Todavia, donos de territórios maiores passaram mais tempo em atividade de forrageamento que donos de territórios menores. Como consequência, donos de territórios maiores tiveram menos tempo para descansar que donos de territórios menores. Os resultados deste trabalho mostram padrões comportamentais importantes para o entendimento da relação entre tamanho e custo de manutenção dos territórios de $P$. nasus e de outras espécies de peixes com comportamento territorial.

Key words: Spatial distribution, Territory size, Foraging, Resting time, Territory defense.

\section{Introduction}

Individuals of the same species have very similar needs to supply their survival, growth and reproduction, but the combined demand over a certain resource may exceed its immediate supply, which can then lead to competition. This competition may result in territorial behavior, where a defined area is defended against intruders by a recognizable behavior pattern (Begon et al., 2003). Territorial defense establishes a minimum spacing between individuals, facilitates co-existence and has been the focus of many observational, experimental and comparative studies, which have attempted to demonstrate both the complexity and the ecological importance of this behavior in several taxa (Adams, 2001).

A number of different factors can lead animals to establish territories, such as the defense of feeding, breeding or refuge sites (Karino, 1998). The behavioral patterns in the defense of these territories may exert a strong effect on the stability and regulation of the population density (Davies \& Houston, 1984; Adams, 2001). The intraspecific variation in the territory may lead to unequal division of resources between individuals and cause changes in growth rates, reproduction and

\footnotetext{
${ }^{1}$ Pós-Graduação em Ecologia e Conservação da Biodiversidade, Universidade Federal de Mato Grosso, 78060-900 Cuiabá, MT, Brazil. sam_ictio@yahoo.com.br(SES)

${ }^{2}$ Centro Universitário de Vila Velha, Unidade Acadêmica II - Biomédicas. Rua Comissário José Dantas de Mello, 21 Boa Vista, $29102-770$ Vila Velha, ES, Brazil.

${ }^{3}$ Laboratório de Ecologia de Populações, Instituto de Biociências, Universidade Federal de Mato Grosso, 78060-900 Cuiabá, MT, Brazil.
} 
mortality, having therefore a strong effect on population dynamics and stability (Adams, 1998).

Many studies of tropical herbivorous fish with territorial behavior have been conducted in order to understand these relationships. Most of these studies were conducted with marine species or with species that use these environments at some stage of their life cycle (Cleveland, 1999; Letourneur, 2000; Ceccarelli et al., 2001; Meadows, 2001; Mumby \& Wabnitz, 2002; Blanchet et al., 2004; Alwany et al., 2005; Jones, 2005; Stradmeyer et al., 2008). Several studies examine territorial behavior amongst cichlids, both in marine and continental water environments (Kohda, 1995; Karino, 1998; Genner et al., 2004; Matsumoto \& Kohda, 2004; Markert \& Arnegard, 2007; Kohda et al., 2008). In Brazil, however, studies of this nature are still rare and sparse (but see Sazima 1980, 1988; Menegatti et al., 2003; Osorio et al., 2006, for some examples).

Parodon nasus, a small fish of the family Parodontidae, seems to be a typical case of a fish that exhibits territorial behavior and defends feeding sites. The species belongs to a genus widely distributed in South America, except in the South Atlantic, Patagonia and main channel of the Amazon River basins (Pavanelli \& Britski, 2003). Parodontids have very different reproductive periods that do not overlap (Barbieri et al., 1983). The pelvic and pectoral fins of individuals in this family are well developed and adapted to stabilize the fish in the fast water and rocky bottom of rivers and streams where they are usually found grazing on algae (Sazima, 1980). Recently, Gomiero \& Braga (2008) classified this species as insectivorous-iliophagous in the Corumbataí River, where $P$. nasus is abundant in a very polluted area with high deposition of organic matter, and Rocha et al. (2009) working with specimens from a stream stretches occupied by dense stands of aquatic macrophytes has classified it as invertivore.

In Camarinha stream, which crosses the Serra das Araras Ecological Station, individuals of $P$. nasus are easily seen between the actively defending feeding areas from intraspecific or inter-specific (from the same functional group) invaders. In the preliminary observations, which led us to the questions in this study, we verified that adults of this species defended well-defined territorial areas and that these areas showed a wide variation in size.

Field studies have shown that animals adjust the size of their territories in response to food availability and pressure from intruders (Eberhard \& Ewald, 1994) and many animals defend feeding sites that are necessary for their growth, reproduction and maintenance (Verner, 1977). Existing models that explain variation in territory size have several components, among which the description of the "cost function" is an important issue for research, because it describes the relationship between cost and the territorial area defended (Adams, 2001). These models suggest that the defense of the territory has high costs in terms of time for feeding, reproduction and injuries resulting from agonistic encounters (Enquist et al., 1990). Moreover, when the territories are adjacent to each other, the size of the territory itself depends not only on the decisions of the residents, but also on the action of each neighbor, which results in a mosaic of territorial areas that are very sensitive to changes in population density (Adams, 1998).

Aiming to contribute to the increasing knowledge of territoriality in continental species of fish, the purpose of this study was to: (1) determine the density and spatial distribution of $P$. nasus in Camarinha stream, (2) describe the resulting interactions from the territorial behavior and (3) investigate whether there is a difference in maintenance costs for different sizes of territories defended by adults of $P$. nasus.

\section{Material and Methods}

\section{Study Area}

Camarinha Stream is located in the Serra das Araras Ecological Station (EESA) (Fig. 1), a Federal Conservation unit administered by the Instituto Chico Mendes de Conservação da Biodiversidade (ICMBio) and occupying an area of 28,700 ha. The EESA is located on the left bank of the Paraguay River in the southwestern State of Mato Grosso, Brazil, within the municipalities of Porto Estrela and Cáceres, between coordinates $15^{\circ} 33^{\prime} \mathrm{S} 57^{\circ} 03^{\prime} \mathrm{W}$ and $15^{\circ} 39^{\prime} \mathrm{S} 57^{\circ} 19^{\prime} \mathrm{W}$ (SAD 69).

The observations were made between September 28 and October 5, 2008, at four sections of the Camarinha Stream, each with eight meters long and, on average, six meters wide. The coordinate for the central point of the study area is $15^{\circ} 39^{\prime} 07^{\prime \prime} S$ $57^{\circ} 13^{\prime} 09^{\prime \prime} \mathrm{W}$. The sampling sections were selected considering the favorable conditions for the species (presence of in the substrate) and ease of observation (water transparency). The minimum distance between any two stretches was 30 meters.

\section{Sampling}

To estimate the density of Parodon nasus and assess whether it has a uniform, random or clumped distribution, an $8 \times 6 \mathrm{~m}$ plot was laid out in each section of the stream, and each one was divided into sub-plots of 2 x $2 \mathrm{~m}$ (area of $4 \mathrm{~m}^{2}$ ). To determine the density of the species, two independent observers, positioned at opposite ends of the sub-plots, counted the individuals.

In order to compare the maintenance cost in different sized

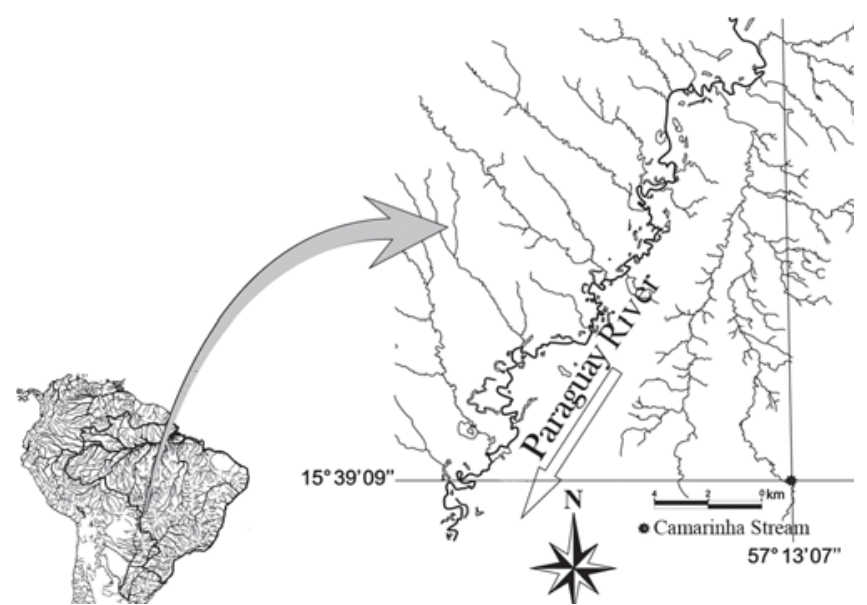

Fig. 1. Study site showing location Camarinha Stream in Serra das Araras, State of Mato Grosso, Brazil. 
territories we observed only individuals of the same class size (adults) that had established territories. This criteria has permitted to isolate the effect of individual size variation on the size of the territories.

The observations of individual behaviors were made through the focal animal method (Lehner, 1979). This method targets a single animal and any behavior that it is observed doing is recorded over a period of time. Each individual of $P$. nasus was observed for 15 minutes. The focal individual was also observed in order to recognize the limits of its territory and its main foraging and resting sites.

During the observation period, the time spent in four main behavioral categories was recorded: (1) foraging, which was the act of scraping the stones or other substrate in search of food; (2) attacking intruders, the act of repelling the entry of other individuals into the limits of the territory by agonistic encounters; (3) resting, when the fish was still, without displaying any type of reaction; (4) patrolling, when the fish made a complete circle around the limits of its territory. In the interactions with other individuals we recorded the identity (belonging or not to the same species).

The behavior used to attack intruders is a very fast movement and was, therefore, measured by occurrence frequency. In order to obtain an estimate of the time spent by each territory owner on this behavior during the 15 minutes of observation, the number of attacks was multiplied by 2 seconds, the approximate time that the individual spends in each attack. The behavior was recorded by a single observer and timed using a simple stopwatch.

To obtain the size of the territory defended by individuals of $P$. nasus, an adaptation of the convex polygon method was used (Odum \& Kuenzler, 1955). This consists in locating the individual at different time intervals to find the borders of its territory. The size of the territory is determined when all the individual movements are restricted to areas that have already been marked. During the observation, the displacement points of the fish were marked with white for easy viewing and, subsequently, the distances were measured to obtain the triangulation of the points and the estimated size of the area of the territory. The observation time required to define the size of a territory varies depending on the activities of the fish, the species studied and the size of the territory (Alwany et al., 2005). In this study, the maximum observation time used to determine the size of the territory of $P$. nasus was set at 10 minutes. However, all territories could be mapped completely before this 10 minutes limit.

The size of individuals was estimated by comparing the fish with an object of known size (7 cm brick), which was positioned in the middle of the territory. To reduce estimation errors, the individuals were grouped in size classes.

\section{Data Analysis}

The average density of individuals of the species in each sub-plot was estimated as the average of the two surveys, conducted independently by two observers. The pattern of spatial distribution of $P$. nasus in each of the four plots (sections of the stream) was evaluated by comparing the observed distribution with the Poisson distribution, which describes random events (Zar, 1999). Among other features, in the Poisson distribution, the ratio of variance to the mean is equal to 1 . A ratio of variance to the mean greater than 1 indicates aggregated distribution and less than 1 indicates uniform distribution (Krebs, 1989). The analysis was performed using a two-tailed $\chi^{2}$ test. $\chi^{2}$ values less than the critical value to 0.975 , for a given degree of freedom, were considered indicators of uniform distribution and those larger than the critical value at 0.025 indicated aggregated distribution (Krebs, 1989). The territory maintenance cost was analyzed by means of scatter plots and linear regression analysis. The total maintenance cost was considered as the sum of the time spent repelling intruders and patrolling the boundaries of the territory. All tests were performed using the statistical package Systat version 12.

\section{Results}

We counted a total of 188.5 (mean, range $=186$ and 191) individuals of $P$. nasus in the four sections sampled. The density was constant in all four sections, with an average of 1.01 ind./ $\mathrm{m}^{2}\left(\mathrm{SD}=0.14\right.$, minimum $=0.93$ ind. $/ \mathrm{m}^{2}$, maximum $\left.=1.31 \mathrm{ind} . / \mathrm{m}^{2}\right)$. The $\chi^{2}$ tests indicated that the individuals are uniformly distributed in section $1\left(\chi^{2}=5.448, \mathrm{df}=15, \mathrm{p}=0.98\right)$. For the remaining sections of the river the spatial distribution was random (section 2: $\chi^{2}=2.421, \mathrm{df}=7, \mathrm{p}=0.93$; section $3: \chi^{2}=$ 6.64, $\mathrm{df}=11, \mathrm{p}=0.82$; section $4: \chi^{2}=11.593, \mathrm{df}=10, \mathrm{p}=0.312$ ).

To determine the behavior pattern, we observed 7 individuals of $P$. nasus per site that defended territories of different sizes. The average size of the individuals studied was $9.1 \mathrm{~cm}$ total length $(\mathrm{SD}=0.5)$ and the size of the territories varied from 0.16 to $1.47 \mathrm{~m}^{2}$ (mean $=0.61 ; \mathrm{SD}=0.3$ ). During the observations, $P$. nasus actively defended the limits of its territory and displayed the same aggressive behavior of attacking intruders independent of their identity (intra or interspecific). The interspecific intruders who were attacked are individuals of the species Apareiodon affinis and Characidium sp., which were also seen scraping stones and searching for food along the substrate. In these encounters, owners chased the intruder to beyond the limits of its territory. In all situations of territory defense observed, the owners of the territories managed to send the intruders away and maintain their territorial limits, regardless of the size of the attacker and its identity.

In the four sections studied, the limits of the territories were more often defended against co-specific intruders than against invaders belonging to other species. Interspecific aggressive encounters were more frequent in sections 1 and 2 , representing respectively $9.5 \%$ and $8.6 \%$ of the agonistic encounters recorded. In section 3 the interspecific agonistic encounters were rare $(0.7 \%)$ and in section 4 all the attacks were with conspecific intruders.

The size of the territories did not affect the time that the owner spent defending it $\left(\mathrm{r}^{2}=0.01, \mathrm{~F}_{1.26}=0.020, \mathrm{p}=0.889\right)$ (Fig. 2a). Individuals with the smallest territories spent as 
much time patrolling their boundaries and repelling intruders (mean $=4.1$ minutes; $\mathrm{SD}=1.9$ ) as those that had larger territories (mean $=4.0, \mathrm{SD}=1.8)\left(\mathrm{r}^{2}=0.01, \mathrm{~F}_{1,26}=0.010, \mathrm{p}=\right.$ 0.920 ) (Fig. 2b). However, owners of larger territories spent more time foraging (mean $=6.8 ; \mathrm{SD}=2$ ) than owners of smaller territories (mean $=5.8 ; \mathrm{SD}=2.9$; model: time foraging $=0.197$ +0.077 size of territory, $\mathrm{r}^{2}=0.171, \mathrm{~F}_{1.26}=5.35, \mathrm{p}=0.029$ ) (Fig. 2c). As a result, owners of larger territories had less time to rest $($ mean $=1 ; \mathrm{SD}=2.1)$ than owners of smaller ones (mean $=$ 2.2; $\mathrm{SD}=3.4$ ) (model: $\ln$ time resting $=1.662-1.559 \ln$ size of territory, $\mathrm{r}^{2}=0.155, \mathrm{~F}_{1.26}=4.772, \mathrm{p}=0.038$ ) (Fig. $2 \mathrm{~d}$ ).
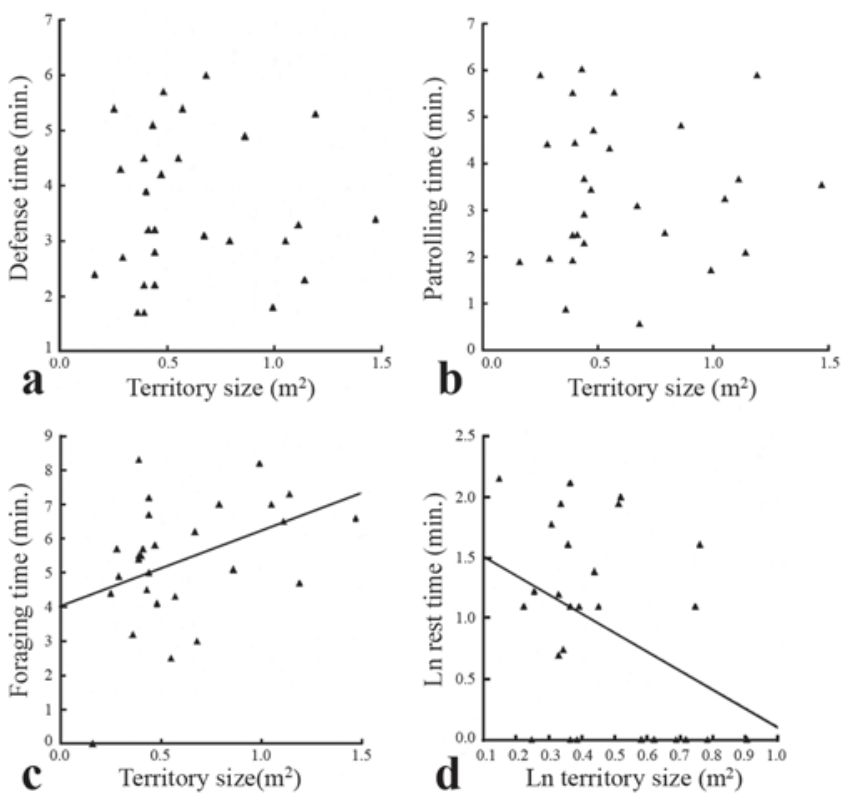

Fig. 2. Relationship between the number of attacks on intruders (a), the time foraging (b) and the time resting (c) with the size of the territory defended by Parodon nasus in a stream in Serra das Araras, State of Mato Grosso, Brazil (October 2008).

\section{Discussion}

The spatial distribution of individuals results from interactions between the organisms themselves and can be aggregated, uniform or random (Ricklefs \& Miller, 1999). According to what we observed in the field, Parodon nasus displays territorial behavior, but only in section 1 was the spatial distribution uniform, which is a common among territorial species (Begon et al., 2003). In other sections of the stream (2, 3 and 4) the distribution was random, which may be the result of the presence of juvenile individuals in these plots, since these did not have fixed territories and foraged randomly. Unfortunately, it was not possible to separate adult individuals from juveniles during the population surveys. Therefore, we cannot confirm whether or not the spatial variation in the dispersal patterns is due to a variation in the proportion of juveniles between the different sections of the river.

In territorial species, the density of the individuals may have a strong effect on their distribution, due to increased competition for resources (pressure of intruders) (Adams, 2001).
Several studies found a strong correlation between the size of territories and different pressures from intruders (e.g., Eberhard \& Ewald, 1994; Iguchi \& Abe, 2002) and one of the most common effects of intruder pressure is a reduction in the area of the territory, which usually occurs with increasing population density (Lopez-Sepulcre \& Kokko, 2005). Moreover, high density of fish can also contribute to an increase in agonistic interactions (Cole \& Noakes, 1980; Maher \& Lott, 2000). In this study, due to fast sampling, the pressure of intrusion (mainly by juveniles) cannot be directly evaluated, but we found that there was no apparent variation in the territorial maintenance costs between the sampled sections (which, nevertheless, showed little variation in density). As the effect of pressure from intruders is sensitive to variation in density, the results suggest that this factor did not have a strong effect on the size of the $P$. nasus's territories in the sampled sections.

It was clear that $P$. nasus defended individual sites for food, since the attacks of the territory owners were usually intraspecific and, when these attacks were interspecific the targets were species that were using the same space to obtain food. Apareiodon affinis, which represented most of the interspecific attacks, belongs to the same trophic group as $P$. nasus (Santin et al., 2004) while Characidium sp., that is classified as insectivorous (Aranha et al., 2000; Barreto \& Aranha, 2006), was more than likely only using the space.

The stronger agonistic behavior towards conspecifics or intruders of the same functional group have been suggested as a benefit to the owner of the territory (Stradmeyer et al., 2008), since the costs of maintenance are reduced by attacking intruders which are potentially harmful, and not any individual that approaches the territory (Harrington \& Losey, 1990; Nakano \& Nagoshi, 1990; Iguchi \& Abe, 2002; Sturmbauer et al., 2008). These behavioral adjustments are important for territorial species as they help them to reach a positive equilibrium between the energy spent to defend the territory and the energy needed for metabolism, growth and reproduction (Blanchet et al., 2006) which typically involve trade-offs, because the time and energy required for a certain activity (e.g. defence of territory) can't be used for another (e.g. foraging) (Hamilton \& Dill, 2003; Hamilton, 2004).

Our results do not support the idea that larger territories are more costly to defend. That is, the energetic cost used in the defense of territories of different sizes, measured as time spent defending and patrolling, did not change significantly with territory size. This finding corroborates the results obtained by Menegatti et al. (2003) and Itzkowitz et al. (2000), who also found no significant differences in the cost of maintaining territories by Stegastes fuscus (in the coast of Espirito Santo State, Brazil) and Stregastes leucostictus (in the reefs of Jamaica), respectively. The agonistic behavior has evolved to be energy efficient (Cleveland, 1999). Thus, the choice of defending larger or smaller territories may be related to other factors that provide immediate benefits, such as more productive areas or ones that provide more shelter. Moreover, there is an optimization with regard to the size of the defended territories that are not necessarily influenced 
by the cost of maintenance, where the need for foraging regulates the minimum size and intra-specific competition determines the maximum size (Grant, 1997).

The inverse relationship between increasing time of foraging and reducing resting time in larger territories may be related to their lower productivity (Letourneur, 2000). In the more productive areas, foraging time may be reduced due to higher quality and density of the available resources (Adams, 2001). Thus, we would expect the observed relationship if smaller territories had greater density/quality of resources when compared to larger ones. While productivity was not quantified in this study, this hypothesis could explain, at least partially, the behavioral trends observed. According to Adams (2001), there is generally a negative correlation between productivity and size of defended territories, that is, as productivity diminishes there is an increase in the size of the territory. Thus, the increase in the area of the defended territory may be a way to compensate for the foraging needs of the individual that defends it.

However, we cannot reject the hypothesis that the density of resources does not vary between territories of different sizes, and that, therefore, the owners of larger territories gain more resources than those of smaller territories (Johnsson et al., 2000; Candolin \& Voigt, 2001). In this case, the more time spent foraging and less time resting in larger territories could be explained if individuals with higher energy requirements, like large-sized fish, occupied these territories (Deverill et al., 1999), leading to a positive relationship between the size of the individual and the size of the area of the defended territory (Bell \& Kramer, 2000; Adams, 2001). However, we would need more accurate measures of the size of the territory owners to be able to test this hypothesis which was, unfortunately, not possible in this study due to sampling difficulties associated to habitat characteristics (speed, transparency and substrate type) and the behavior of the individuals. Thus, the data presented here do not allow us to choose between these two hypotheses.

Factors such as density, productivity and establishment of value zones within the territories should be considered and further evaluated in order to fully understand the factors that govern the dynamics of territorial behavior in $P$. nasus. Moreover, the results of this study show that behavioral trends can be important tools for understanding the relationship between size and cost of maintaining the territories of $P$. nasus and other species of fish with territorial behavior.

\section{Acknowledgements}

We are very grateful to Guilherme Mourão and Caroline Leuchtenberger for critical reading of early drafts. Two anonymous referees have improved the initial version of this paper. Financial support was provided by CAPES (PROAP) and UFMT. This work was supported by graduate fellowships from Conselho Nacional de Desenvolvimento Científico e Tecnológico (CNPq) to S. E. Silva and Fundação de Amparo à Pesquisa do Estado de Mato Grosso (FAPEMAT) to W. R. C.
Assunção. This research was conducted as part of an ecology field course provided by the Ecology Graduate Program of the Universidade Federal de Mato Grosso. Thanks to the staff of Estação Ecológica de Serra das Araras (EESA - ICMBio), mainly Rafael Valadão, for logistical support, and permits to conduct the activities.

\section{Literature Cited}

Adams, E. S. 1998. Territory size and shape in fire ants: a model based on neighborhood interactions. Ecology, 79(4): 1125-1134.

Adams, E. S. 2001. Approaches to the study of territory size and shape. Annual Review of Ecology and Systematics, 32: 277-303.

Alwany, M., E. Thaler \& M. Stachowitsch. 2005. Territorial behaviour of Acanthurus sohal and Plectroglyphidodon leucozona on the fringing Egyptian Red Sea reefs. Environmental Biology of Fishes, 72: 321-334.

Aranha, J. M. R., J. H. C. Gomes \& F. N. O. Fogaça. 2000. Feeding of two sympatric species of Characidium, C. lanei and C. pterostictum (Characidiinae) in a coastal stream of Atlantic Forest (Southern Brazil). Brazilian Archives of Biology and Technology, 43(5): 527-531.

Barbieri, G., J. R. Verani \& M. C. Barbieri. 1983. Análise do comportamento reprodutivo das espécies Apareiodon affinis (Steindachner, 1879), Apareiodon ibitiensis (Campos, 1944) e Parodon tortuosus (Eigenmann and Norris, 1900) do rio PassaCinco, Ipeúna, São Paulo (Pisces, Parodontidae). Pp. 189-199. In: Anais do Seminário Regional Ecologia III. São Carlos, São Paulo.

Barreto, A. P. \& J. M. R. Aranha. 2006. Alimentação de quatro espécies de Characiformes de um riacho da Floresta Atlântica, Guaraqueçaba, Paraná, Brasil. Revista Brasileira de Zoologia, 23(3): 779-788.

Begon, M., C. R. Townsend \& J. L. Harper. 2003. Ecology: individuals, populations and communities. Blackwell Scientific Publications, London, 945p.

Bell, T. \& D. L. Kramer. 2000. Territoriality and habitat use by juvenile blue tangs, Acanthurus coeruleus. Environmental Biology of Fishes, 58: 401-409.

Blanchet, S., J. J. Dodson \& S. Brosse. 2006. Influence of habitat structure and fish density on Atlantic salmon Salmo salar L. territorial behaviour. Journal of Fish Biology, 68(3): 951-957.

Candolin, U. \& R. H. Voigt. 2001. Correlation between male size and territory quality: consequence of male competition or predation susceptibility? Oikos, 95: 225-230.

Casatti, L., H. F. Mendes \& K. M. Ferreira. 2003. Aquatic macrophytes as feeding site for small fishes in the Rosana Reservoir, Paranapanema River, Southeastern Brazil. Brazilian Journal of Biology, 63(2): 213-222.

Ceccarelli, D. M., G. P. Jones \& L. S. McCook. 2001. Territorial damselfish as determinants of the structure of benthic communities on coral reef. Oceanograph and Marine Biology: an Annual Review, 39: 355-389.

Cleveland, A. 1999. Energetic costs of agonistic behavior in two herbivorous damselfishes (Stegastes). Copeia, 1999(4): 857-856.

Cole, K. S. \& D. L. G. Noakes. 1980. Development of early social behaviour of rainbow trout, Salmo gairdneri (Pisces, Salmonidae). Behavioural Processes, 5: 97-112.

Davies, N. B. \& A. I. Houston. 1984. Territory economics. Pp. 148-169. In: Krebs, J. R. \& N. B. Davies (Eds.). Behavioural Ecology: an evolutionary approach. Oxford, Blackwell, 456p. 
Deverill, J. I., C. E. Adams \& C. W. Bean. 1999. Prior residence, aggression and territory acquisition in hatchery-reared and wild brown trout. Journal of Fish Biology, 55(4): 868-875.

Eberhard, J. C. \& P. W. Ewald. 1994. Food availability, intrusion pressure and territory size: an experimental study of Anna's hummingbirds (Calyote anna). Behavioral Ecology and Sociobiology, 34: 11-18.

Enquist, M., O. Leimar, T. Ljungberg, Y. Mallner \& N. Segerdahi. 1990. A test of sequential assessment game: fighting in the cichlid fish Nannacara anomala. Animal Behavior, 40: 1-14.

Genner, M. J., G. F. Turner \& S. J. Hawkins. 2004. Resource control by territorial male cichlid fish in Lake Malawi. Journal of Animal Ecology, 68: 522-529.

Gomiero, L. M. \& F. M. S. Braga. 2008. Feeding habits of the ichthyofauna in a protected area in the state of São Paulo, southeastern Brazil. Biota Neotropica, 8(1): 40-47.

Grant, J. W. A. 1997. Territoriality. Pp. 81-103. In: Godin, J. G. (Ed.). Behavioural Ecology of Teleost Fishes. New York, Oxford University Press, 400p.

Hamilton, I. M. 2004. Distance to neighbours influences the tradeoff between hiding after disturbance and defending food patches in convict cichlids (Archocentrus nigrofasciatus). Behavioral Ecology and Sociobiology, 56(6): 530-538.

Hamilton, I. M. \& L. M. Dill. 2003. The use of territorial gardening versus kleptoparasitism by a subtropical reef fish (Kyphosus cornelii) is influenced by territory defendability. Behavioral Ecology, 14: 561-568.

Harrington, M. E. 1995. Aggression in damselfish: habituation by adults of Pomacentrus partitus to juvenile intruders. Environmental Biology of Fishes, 42(1): 25-35.

Harrington, M. E. \& G. S. Losey. 1990. The importance of species identification and location on interspecific territorial defense by the damselfish, Stegastes fasciolatus. Environmental Biology of Fishes, 27: 139-145.

Iguchi, K. \& S. Abe. 2002. Territorial defense of an excess food supply by an algal grazing fish, ayu. Ecological Research, 17: 373-380.

Itzcowitz, M., A. Ludlow \& M. Haley. 2000. Territorial boundaries of the male beaugregory damselfish. Journal of Fish Biology, 56: $1138-1144$.

Johnsson, J. I., M. Carlsson \& L. F. Sundström. 2000. Habitat preferences increases territorial defence in brown trout (Salmo trutta). Behavioral Ecology and Sociobiology, 48: 373-377.

Jones, K. M. M. 2005. The effect of territorial damselfish (family Pomacentridae) on the space use and behaviour of the coral reef fish, Halichoeres bivittatus (Bloch, 1791) (family Labridae). Journal of Experimental Marine Biology and Ecology, 324(2): 99-111.

Karino, K. 1998. Depth-related differences in territory, size and defense in the herbivorous cichlid, NeoIamprologus moorii, in Lake Tanganyika. Ichthyological Research, 45(1): 89-94.

Kohda, M. 1995. Territoriality of male cichlid fishes in Lake Tanganyika. Ecology of Freshwater Fish, 4: 180-184.

Kohda, M., J. Shibata, S. Awata, D. Gomagano, T. Takeyama, M. Hori \& D. Heg. 2008. Niche differentiation depends on body size in a cichlid fish: a model system of a community structured according to size regularities. Journal of Animal Ecology, 77: 859-868.

Krebs, C. J. 1989. Ecological methodology. New York, Harper Collins Publishers, 654p.

Lehner, P. N. 1979. Handbook of ethological methods. New York, Garland STPM Press, 403p.

Letourneur, Y. 2000. Spatial and temporal variability in territoriality of a tropical benthic damselfish on a coral reef (Reunion Island). Environmental Biology of Fishes, 57(4): 377-391.
Lopez-Sepulcre, A. \& H. Kokko. 2005. Territorial defense, territory size, and population regulation. American Naturalist, 166(3): 317-329.

Maher, C. R. \& D. L. Lott. 2000. A review of ecological determinants of territoriality within vertebrate species. American Midland Naturalist, 143: 1-29.

Markert, J. \& M. Arnegard. 2007. Size-dependent use of territorial space by a rock-dwelling cichlid fish. Oecologia, 154(3): 611-621.

Matsumoto, K. \& M. Kohda. 2004. Territorial defense against various food competitors in theTanganyikan benthophagous cichlid Neolamprologus tetracanthus. Ichthyological Research, 51: 354-359.

Meadows, D. W. 2001. Centre-edge differences in behaviour, territory size and fitness in clusters of territorial damselfish: patterns, causes and consequences. Behaviour, 138: 1085-1116.

Menegatti J. V., D. L. Oscar \& S. R. Flater. 2003. Interações agonísticas e forragemento de peixes donzela, Stegastes fuscus (Perciformes: Pomacentridae). Natureza on line, 1(2): 45-50.

Mumby, P. J. \& C. C. C. Wabnitz. 2002. Spatial patterns of aggression, territory size, and harem size in five sympatric Caribbean parrotfish species. Environmental Biology of Fishes, 63(3): 265-279.

Nakano, S. \& M. Nagoshi. 1990. Brood defense and parental roles in a biparental cichlid fish Lamprologus toae in Lake Tanganyika. Japanese Journal of Ichthyology, 36: 468-476.

Odum, E. P. \& E. J. Kuenzler. 1955. Measurement of territory size and home range size in birds. The Auk, Lawrence, 72: 128-137.

Osorio, R., I. L. Rosa \& H. Cabral. 2006. Territorial defence by the Brazilian damsel Stegastes fuscus (Teleostei: Pomacentridae). Journal of Fish Biology, 69(1): 233-242.

Pavanelli, C. S. \& H. A. Britski. 2003. Apareiodon Eigenmann, 1916 (Teleostei, Characiformes), from the Tocantins-Araguaia Basin, with description of three new species. Copeia, 2003(2): 337-348.

Ricklefs, R. E. \& G. L. Miller. 1999. Ecology. $4^{\text {th }}$ ed. New York, W.H. Freeman and Company, 822p.

Rocha, F. C., L. Casatti, F. R. Carvalho \& A. M. Silva. 2009. Fish assemblages in stream stretches occupied by cattail (Typhaceae, Angiospermae) stands in Southeast Brazil. Neotropical Ichthyology, 7(2): 241-250.

Santin, M., A. Bialetzki \& K. Nakatani. 2004. Mudanças ontogênicas no trato digestório e dieta de Apareiodon affinis (Steindachner, 1879) (Osteichthyes, Parodontidae). Acta Scientiarum, Biological Sciences, 26(3): 291-298.

Sazima, I. 1980. Behavior of two Brazilian species of parodontid fishes, Apareiodon piracicabae and A. ibitiensis. Copeia, 1980(1): 166-169.

Sazima, I. 1988. Territorial behaviour in a scale-eating and a herbivorous neotropical characiform fish. Revista Brasileira de Biologia, 48(2): 189-194.

Stradmeyer, L., J. Hojesjo, S. W. Griffiths, D. J. Gilvear \& J. D. Armstrong. 2008. Competition between brown trout and Atlantic salmon parr over pool refuges during rapid dewatering. Journal of Fish Biology, 72(4): 848-860.

Sturmbauer, C., C. Hahn, S. Koblmuller, L. Postl \& K. M. Sefc. 2008. Variation of territory size and defense behavior in breeding pairs of the endemic Lake Tanganyika cichlid fish Variabilichromis moorii. Hydrobiologia, 615: 49-56.

Verner, J. 1977. On the adaptive significance of territoriality. The American Naturalist, 111(980): 769-775.

Zar, J. H. 1999. Biostatistical analysis. $4^{\text {th }}$ edition. New Jersey, Prentice-Hall, 663p.

Accepted September 7, 2009 Published December 18, 2009 